\title{
Deoxypodophyllotoxin induces cell cycle arrest and apoptosis in human cholangiocarcinoma cells
}

\author{
MEIFANG XIAO ${ }^{1}$, XUEGONG FAN $^{2}$, YONGMING FU ${ }^{2}$, YUJUAN ZHOU ${ }^{3}$, SHAOHUI LIU $^{1}$ and SHIFANG PENG $^{1,2}$ \\ Departments of ${ }^{1}$ Health Management Center and ${ }^{2}$ Infectious Diseases, \\ Xiangya Hospital, Central South University, Changsha, Hunan 410008; ${ }^{3}$ Department of Radiotherapy, \\ Hunan Cancer Hospital, Changsha, Hunan 410013, P.R. China
}

Received February 28, 2016; Accepted February 7, 2017

DOI: $10.3892 / \mathrm{ol} .2018 .8978$

\begin{abstract}
Deoxypodophyllotoxin (DPT), a naturally occurring flavolignan, has a broad range of biological effects, including anti-inflammatory, anti-viral and anticancer properties. The present study investigated the anti-proliferative effect of DPT on human cholangiocarcinoma QBC939 and RBE cell lines and its underlying mechanisms of inducing cytotoxicity. MTT assays demonstrated that DPT inhibited the viability of the QBC939 and RBE cells in a dose and time-dependent manner. In addition, DPT treatment resulted in G2/M phase cell cycle arrest associated with the downregulation of Cyclin B and cyclin dependent kinase 1 and caused an increase in apoptosis that was confirmed by characteristic morphological changes. Apoptosis was accompanied by increasing B-cell lymphoma-2 (Bcl-2)/Bcl-2 associated $\mathrm{X}$ protein ratios and activated expression of caspase-3, -8 and -9 . These findings suggested that DPT may be a novel anticancer agent against human cholangiocarcinoma.
\end{abstract}

\section{Introduction}

Cholangiocarcinoma is the second most common type of primary liver malignancy globally (1), accounting for $\sim 3 \%$ of gastrointestinal tumors and $10-25 \%$ of all hepatobiliary malignancies. The incidence rate of cholangiocarcinoma is increasing, particularly that of intrahepatic cholangiocarcinoma (2). However, despite advances in imaging, diagnosis and surgical techniques, the 5-year overall survival rate for cholangiocarcinoma is only $20-40 \%$ following potentially curative surgery, while the median survival period is 22 months (3).

Natural products and their derivatives are valuable chemical resources that may be used in the treatment and

Correspondence to: Professor Shifang Peng, Department of Health Management Center, Xiangya Hospital, Central South University, 87 Xiangya Road, Changsha, Hunan 410008, P.R. China

E-mail: shifang70peng@126.com

Key words: deoxypodophyllotoxin, cholangiocarcinoma, proliferation, $\mathrm{G} 2 / \mathrm{M}$ arrest, apoptosis prevention of cancer (4). Deoxypodophyllotoxin (DPT), an analog of podophyllotoxin isolated from Anthriscussylvestris roots, has been extensively studied due to its multiple pharmacological activities. DPT exhibits antitumor effects on HeLa cells, glioblastoma and non-small cell lung, gastric and breast cancer (5-13), anti-inflammatory (14) and anti-viral (15) activities. There is an increasing amount of evidence demonstrating that DPT inhibits proliferation in cultured cancer cells by inducing apoptosis and or cell cycle arrest (8-13).

To the best of our knowledge, the present study is the first of its kind to examine the antitumor effect of DPT on human cholangiocarcinoma cells, including its effects on cellular growth and apoptosis rate, as well as the underlying mechanisms.

\section{Materials and methods}

Materials.DPT was purchased from Yunnan Xili Pharmaceutical Company (Kunming, China). The human cholangiocarcinoma QBC939 and RBE cell cells were purchased from the Cell Bank of Type Culture Collection of Chinese Academy of Sciences (Shanghai, China). All cell culture reagents were obtained from Gibco; Thermo Fisher Scientific, Inc. (Waltham, MA, USA). An Annexin V-fluorescein isothiocyanate (FITC) apoptosis detection kit and propidium iodide (PI)/RNase staining buffer were purchased from Calbiochem (EMD Millipore, Billerica, MA, USA). MTT, dimethyl sulfoxide (DMSO), Hoechst 33258, and antibodies were obtained from Sigma-Aldrich; Merck KGaA (Darmstadt, Germany).

Cell lines. The human cholangiocarcinoma QBC939 and RBE cell lines were cultured in RPMI-1640 medium, supplemented with $10 \%(\mathrm{v} / \mathrm{v})$ heat-inactivated fetal bovine serum, penicillin $(100 \mathrm{U} / \mathrm{ml})$ and streptomycin $(100 \mu \mathrm{g} / \mathrm{ml})$. The cultures were maintained in a $5 \% \mathrm{CO}_{2}$ humidified atmosphere at $37^{\circ} \mathrm{C}$.

Growth inhibitory evaluation. The MTT growth inhibition method was used to assess the cytotoxicity of DPT as described previously (16). Briefly, QBC939 and RBE cells were seeded in 96-well plates $\left(4 \times 10^{3}\right.$ cells/well). Following a $24 \mathrm{~h}$ incubation at $37^{\circ} \mathrm{C}$ to allow for attachment, the cells were incubated with or without various concentrations of DPT $(0,0.05,0.1,0.5$ and $1 \mu \mathrm{M})$ for indicated intervals $(0,24,48$ or $72 \mathrm{~h})$. Subsequently, 
$20 \mu \mathrm{l}$ MTT dye solution $(5 \mathrm{mg} / \mathrm{ml}$ in phosphate buffer; $\mathrm{pH} 7.4)$ was added to each well and the cells were incubated for an additional $4 \mathrm{~h}$, prior to the addition of DMSO for color development. Metabolic activity was quantified by measuring light absorbance at $570 \mathrm{~nm}(17)$.

Flow cytometry for cell cycle analysis. Following a $24 \mathrm{~h}$ incubation at $37^{\circ} \mathrm{C}$ to allow for attachment, QBC939 and RBE cholangiocarcinoma cells $\left(1 \times 10^{6}\right.$ cells/well $)$ were seeded in 6-well plates and treated with DPT for $48 \mathrm{~h}$ in a concentration range of $0-1 \mu \mathrm{M}$. The cells were washed with PBS (pH 7.4) and fixed with $80 \%$ ice-cold ethanol at $4^{\circ} \mathrm{C}$ overnight. The cells were subsequently treated with $80 \mathrm{mg} / \mathrm{ml}$ RNase and $50 \mathrm{mg} / \mathrm{ml} \mathrm{PI}$ in the dark for $30 \mathrm{~min}$, and analyzed using a Coulter Epics XL Flow Cytometer (Beckman Coulter, Inc., Miami, FL, USA).

Hoechst 33258 staining. A fluorescent morphological assay (18) was performed to detect the apoptosis induced by DPT. In total, $1 \times 10^{6}$ cells were seeded in 6-well plates and allowed to attach overnight. Thereafter the cells were treated with $0.5 \mu \mathrm{M}$ DPT or solvent control (Fresh medium without serum) for $48 \mathrm{~h}$. The cells were subsequently washed twice with PBS and fixed using 4\% formaldehyde for $15 \mathrm{~min}$. Subsequently, cells were washed in PBS and stained with $50 \mu 1$ of Hoechst 33258 solution (50 ng/ml in PBS; Sigma-Aldrich; Merck $\mathrm{KGaA}$ ) for $15 \mathrm{~min}$ at $4^{\circ} \mathrm{C}$ in the dark and subsequently examined using an Olympus FV1000 fluorescent microscope (Olympus Corporation, Tokyo, Japan) at $356 \mathrm{~nm}$.

Analysis of apoptosis. Induction of apoptosis by DPT was assessed by the binding of Annexin $\mathrm{V}$ to phosphatidylserine, which is externalized to the outer leaflet of the plasma membrane early during the induction of apoptosis. For Annexin V-FITC binding, QBC939 and RBE cells were treated with DPT for $48 \mathrm{~h}$, harvested and resuspended in the binding buffer provided in the Annexin V-FITC apoptosis detection kit. Cells were reacted with $5 \mu \mathrm{l}$ Annexin V-FITC reagent and $5 \mu \mathrm{l}$ PI for $30 \mathrm{~min}$ at room temperature in the dark. Stained cells were analyzed by flow cytometry.

Western blot analysis. Following treatment with 0, 0.05, $0.1,0.5$ or $1 \mu \mathrm{M}$ DPT for $48 \mathrm{~h}$, the cells were washed twice with PBS, and lysed using radioimmunoprecipitation assay buffer (20 mM Tris, pH 7.5; $150 \mathrm{mM} \mathrm{NaCl} ; 1 \%$ Triton X-100; $2.5 \mathrm{mM}$ sodium pyrophosphate; $1 \mathrm{mM}$ EDTA; $1 \% \mathrm{Na}_{3} \mathrm{CO}_{4}$; $0.5 \mathrm{~g} / \mathrm{ml}$ leupeptin; $1 \mathrm{mM}$ phenylmethanesulfonyl fluoride) on ice to obtain the protein. Lysates were subsequently centrifuged at $13,400 \mathrm{x}$ g for $15 \mathrm{~min}$ at $4^{\circ} \mathrm{C}$. The supernatant was collected and total protein concentrations were measured using a bicinchoninic acid assay (Pierce; Thermo Fisher Scientific, Inc.). Mitochondria and cytosol were separated by differential ultracentrifugation (19). A total of $30 \mu \mathrm{g}$ protein lysate was separated by $10 \%$ SDS-PAGE and electrophoretically transferred to a polyvinylidene difluoride membrane (Immunobilon-P, 0.45 mm; EMD Millipore, Billerica, MA, USA) using the TE 77 Semi-Dry Transfer Unit (GE Healthcare Life Sciences, Buckinghamshire, UK). The blot was blocked in blocking buffer (5\% non-fat dry milk; $1 \%$ Tween-20 in PBS) for $1 \mathrm{~h}$ at room temperature, incubated with the following specific primary antibodies: Cyclin B (cat no. sc-166210), cyclin-dependent kinase 1 (CDK1; cat no. sc-53219), Bcl-2 associated X protein (Bax; cat no. sc-80658), B-cell lymphoma-2 (Bcl-2; cat no. sc-509), cleaved caspase-3 (cat no. sc-271759), cleaved caspase-8 (cat no. sc-5263), cleaved caspase-9 (cat no. sc-17784) and $\beta$-actin (all the primary antibodies were purchased from Santa Cruz Biotechnology, Inc., Santa Cruz, CA, USA) at a dilution of 1:1,000 overnight at $4^{\circ} \mathrm{C}$. Subsequently, blots were incubated with the corresponding horseradish peroxidase conjugated secondary antibody (cat no. sc-2350, Santa Cruz Biotechnology, Inc.) at a dilution of 1:2,000 for $1 \mathrm{~h}$ at room temperature. The signal was visualized with the Enhanced Chemiluminescence Plus detection system (GE Healthcare Life Sciences, Shanghai, China). Protein bands were semi-quantified by densitometric analysis using ImageJ 1.43 software (National Institutes of Health, Bethesda, MA, USA). The densitometry readings of the bands were normalized according to $\beta$-actin expression.

Statistical analysis. All experiments were repeated $\geq 3$ times. The data are presented as the mean \pm standard deviation and processed using SPSS software (version 13.0; SPSS Inc., Chicago, IL, USA). Statistical analyses were performed using either an unpaired or two-tailed Student's t-test or one-way analysis of variance. Post-hoc analysis between the groups was performed using Student-Newman-Keuls method. $\mathrm{P}<0.05$ was considered to indicate a statistically significant difference.

\section{Results}

DPT inhibits the viability of QBC939 and RBE cells. The growth inhibition effect of DPT on QBC939 and RBE cellular viability was determined using an MTT assay. As presented in Fig. 1, DPT induced a dose and time-dependent inhibition of the cellular viability of QBC939 and RBE cells following the treatment in vitro. The $50 \%$ growth inhibition concentration $\left(\mathrm{IC}_{50}\right)$ of QBC939 was estimated to be 1.186, 0.779 and $0.460 \mu \mathrm{M}$ for 24,48 and $72 \mathrm{~h}$, respectively. The $\mathrm{IC}_{50}$ of RBE was estimated to be $1.138,0.726$ and $0.405 \mu \mathrm{M}$ for 24,48 and $72 \mathrm{~h}$, respectively.

DPT induced G2/M phase arrest in QBC939 and RBE cells. The effect of DPT on cell cycle profile was analyzed using flow cytometry. QBC939 and RBE cells were treated with 0 , $0.05,0.1,0.5$ and $1 \mu \mathrm{M}$ of DPT for $48 \mathrm{~h}$ and their distribution in the different phases of the cell cycle was calculated. The population of cells in $\mathrm{G} 2 / \mathrm{M}$ phase increased and that in $\mathrm{S}$ phase decreased in a dose-dependent manner. For the QBC939 cells, the percentage of cells in $\mathrm{S}$ phase decreased from $61.5 \pm 5.9$ to $29.3 \pm 7.3 \%$, while those in $\mathrm{G} 2 / \mathrm{M}$ phase increased from $11.5 \pm 2.9$ to $49.1 \pm 5.6 \%$ (Table I). For the RBE cells, the percentage of cells in $S$ phase decreased from $61.4 \pm 6.1$ to $35.5 \pm 4.7 \%$, while those in $\mathrm{G} 2 / \mathrm{M}$ phase increased from $12.0 \pm 2.4$ to $46.7 \pm 4.4 \%$ (Table II).

Morphological changes caused by DPT. Control and DPT treated cells were stained with the fluorescent dye Hoechst 33528 and visualized using a fluorescent microscope. The control cells were normal, and the nuclei were round and homogeneous (Fig. 2A), whereas QBC939 (Fig. 2B) and RBE (Fig. 2C) cells treated with DPT exhibited cell shrinkage, 
A<smiles>COc1cc([C@H]2c3cc4c(cc3CC3COC(=O)C32)OCO4)cc(OC)c1OC</smiles>

B

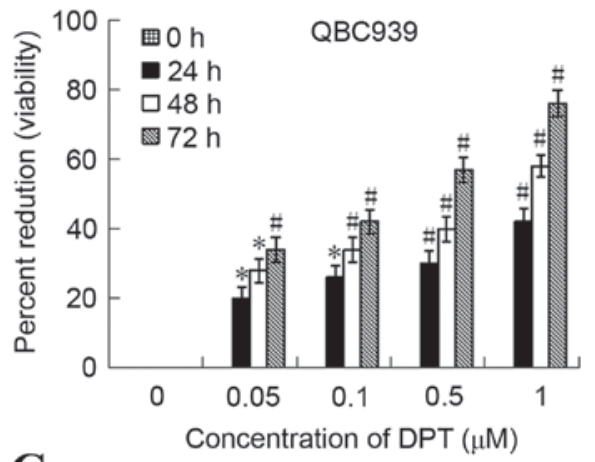

C

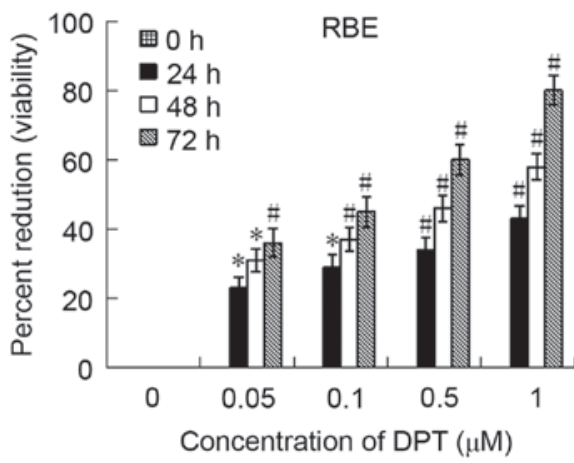

Figure 1. Effects of DPT on the cellular viability of QBC939 and RBE cells. (A) The structure of DPT. (B) QBC939 and (C) RBE cells were incubated in the absence or presence of various concentrations of DPT for 24 , 48 and $72 \mathrm{~h}$, respectively. All data are presented as the mean \pm standard deviation of the 3 separate experiments. ${ }^{*} \mathrm{P}<0.05$ and ${ }^{* *} \mathrm{P}<0.01$ vs. control. DPT, deoxypodophyllotoxin.

chromatin condensation and nuclear deformation and disassembly, which are all features indicative of apoptosis.

Effects of DPT on QBC939 and RBE cell apoptotic induction. The effects of DPT on cellular apoptosis were analyzed using flow cytometry. Subsequent to QBC939 and RBE cells being treated with various concentrations of DPT for $48 \mathrm{~h}$, cells were stained with Annexin V-FITC and PI. As presented in Fig. 2D, the percentage of Annexin V-FITC binding QBC939 cells treated with DPT increased in a concentration-dependent manner from $17 \%$ at $0.05 \mu \mathrm{M}$ DPT to $60 \%$ at $1 \mu \mathrm{M} \mathrm{DPT}$. As shown in Fig. 2E, the percentage of Annexin V-FITC binding RBE cells treated with DPT increased in concentration-dependent manner from $19 \%$ at $0.05 \mu \mathrm{M}$ DPT to $68 \%$ at $1 \mu \mathrm{M}$ DPT.

Effects of DPT on cell cycle regulators. In order to reveal the mechanisms underlying the G2/M arrest observed subsequent to the addition of DPT, western blotting was used to determine
Table I. Effect of DPT on cell cycle profile of QBC939 cells analyzed using FACScan analysis.

\begin{tabular}{lllc}
\hline DPT $(\mu \mathrm{M})$ & G0/G1 & G2/M & S \\
\hline 0 & $27.0 \pm 5.6$ & $11.5 \pm 2.9$ & $61.5 \pm 5.9$ \\
0.05 & $25.1 \pm 4.8^{\mathrm{a}}$ & $19.5 \pm 3.5^{\mathrm{a}}$ & $55.4 \pm 4.8^{\mathrm{a}}$ \\
0.1 & $24.3 \pm 4.4^{\mathrm{a}}$ & $26.5 \pm 5.9^{\mathrm{b}}$ & $49.2 \pm 6.1^{\mathrm{a}}$ \\
0.5 & $20.8 \pm 4.2^{\mathrm{b}}$ & $39.7 \pm 5.0^{\mathrm{b}}$ & $39.5 \pm 7.5^{\mathrm{b}}$ \\
1 & $21.6 \pm 3.8^{\mathrm{b}}$ & $49.1 \pm 5.6^{\mathrm{b}}$ & $29.3 \pm 7.3^{\mathrm{b}}$ \\
\hline
\end{tabular}

${ }^{\mathrm{a}} \mathrm{P}<0.05$ and ${ }^{\mathrm{b}} \mathrm{P}<0.01$ vs. control group $(0 \mu \mathrm{M} / 1 \mathrm{DPT})$. Data represents the mean \pm standard deviation. DPT, deoxypodophyllotoxin.

Table II. Effect of DPT on cell cycle profile of RBE cells by FACScan analysis.

\begin{tabular}{lllc}
\hline DPT $(\mu \mathrm{M})$ & G0/G1 & G2/M & S \\
\hline 0 & $26.6 \pm 5.2$ & $12.0 \pm 2.4$ & $61.4 \pm 6.1$ \\
0.05 & $23.5 \pm 4.9^{\mathrm{a}}$ & $19.2 \pm 3.0^{\mathrm{a}}$ & $57.3 \pm 4.3^{\mathrm{a}}$ \\
0.1 & $23.9 \pm 4.2^{\mathrm{a}}$ & $26.3 \pm 5.6^{\mathrm{b}}$ & $49.8 \pm 5.2^{\mathrm{a}}$ \\
0.5 & $19.1 \pm 4.3^{\mathrm{b}}$ & $40.3 \pm 4.5^{\mathrm{b}}$ & $40.6 \pm 7.3^{\mathrm{b}}$ \\
1 & $17.8 \pm 3.5^{\mathrm{b}}$ & $46.7 \pm 4.4^{\mathrm{b}}$ & $35.5 \pm 4.7^{\mathrm{b}}$
\end{tabular}

${ }^{\mathrm{a}} \mathrm{P}<0.05$ and ${ }^{\mathrm{b}} \mathrm{P}<0.01$ vs. control group $(0 \mu \mathrm{M} / 1 \mathrm{DPT})$. Data represents the mean \pm standard deviation. DPT, deoxypodophyllotoxin.

the expression levels of cell cycle-regulating proteins including Cyclin B1 and CDK1. The present results revealed that DPT treatment resulted in a significant reduction in the protein levels of Cyclin B1 and CDK1 in a dose dependent manner (Fig. 3).

Effects of DPT on apoptosis regulators. To examine the mechanisms underlying the apoptosis observed following the addition of DPT, western blot analysis was used to determine the expression levels of apoptosis-associated proteins including Bax, Bcl-2, cleaved caspase-3, -8 and -9. DPT treatment resulted to a significant reduction in the protein levels of cleaved caspase-3, -8 , and -9 in a dose-dependent manner (Fig. 3). In addition, the expression level of Bax in DPT-treated cells was greatly increased, and accompanied by the downregulation of Bcl-2 expression levels (Fig. 3). Therefore, the ratios of $\mathrm{Bax} / \mathrm{Bcl}-2$ were notably increased in a dose-dependent manner.

\section{Discussion}

DPT has been widely used to treat numerous diseases due to its anti-inflammatory and antitumoral effects (5-13). However, the effect of DPT on human cholangiocarcinoma cells remains unclear. The present study demonstrated that DPT exhibited a significantly inhibitory effect on the proliferation of cholangiocarcinoma cells (QBC939 and RBE) in a time and concentration-dependent manner. The $\mathrm{IC}_{50}$ of DPT was $~ 1.186,0.779$ and $0.460 \mu \mathrm{M}$ in QBC939 cells and $1.138,0.726$ and $0.405 \mu \mathrm{M}$ in RBE cells for 24,48 and $72 \mathrm{~h}$, 


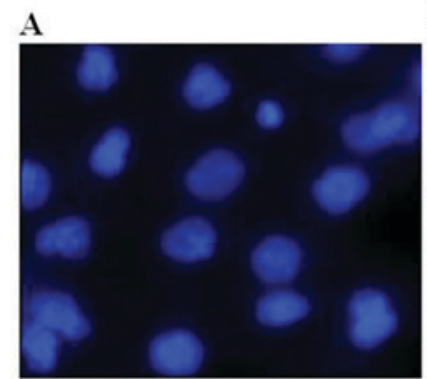

。

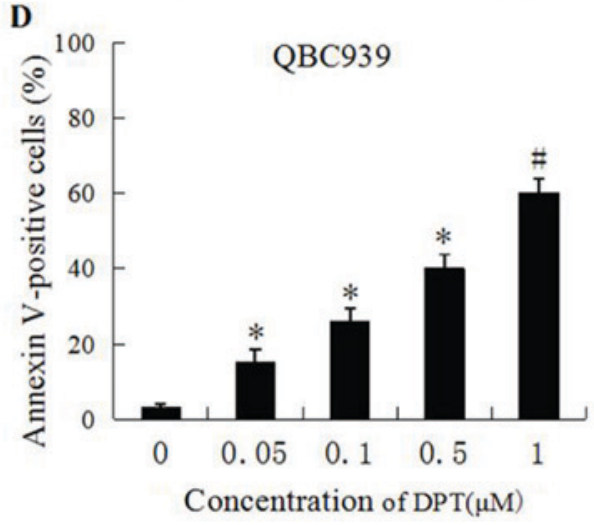

B

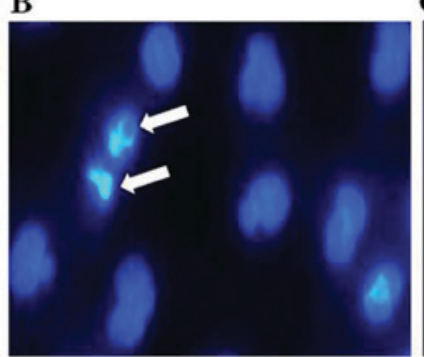

$\mathbf{E}$
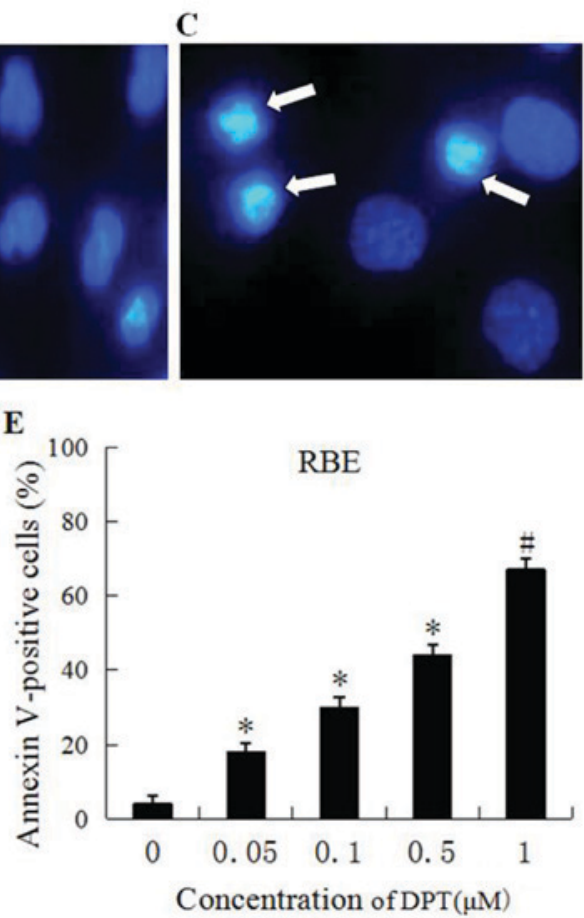

Figure 2. DPT induced the apoptosis of QBC939 and RBE cells. Morphological changes of cholangiocarcinoma cells following treatment with $(0.5 \mu \mathrm{M})$ or without DPT for $48 \mathrm{~h}$. White arrows indicate apoptoticcells. (A) Untreated cells and (B) QBC939 cells and (C) RBE cells treated with DPT stained with fluorescent dye Hoechst 33528 were visualized using fluorescence microscopy. Flow cytometric analysis of cells treated with DPT. (D) QBC939 and (E) RBE cells were exposed to various concentrations of DPT $(0,0.05,0.1,0.5$ and $1 \mu \mathrm{M})$ for $48 \mathrm{~h}$ at $37^{\circ} \mathrm{C}$ in an atmosphere of $5 \% \mathrm{CO}_{2}$. Cells collected were subjected to Annexin V-fluorescein isothiocyanate/propidium iodide staining and analyzed by flow cytometry. ${ }^{*} \mathrm{P}<0.05$ and ${ }^{* * *} \mathrm{P}<0.01$ vs. control. DPT, deoxypodophyllotoxin.

respectively. Additional analysis revealed that DPT exerted clear cytotoxic activity against human cholangiocarcinoma cells, primarily via cell cycle arrest at the $\mathrm{G} 2 / \mathrm{M}$ phase associated with the decrease of the Cyclin B1 and CDK1 and apoptosis induction, which was verified by the typical apoptotic morphological changes and the significant increase in apoptotic cell populations. The present study also identified that the apoptosis of cholangiocarcinoma cells induced by DPT involves intrinsic and extrinsic pathways.

It is known that cellular growth and proliferation of mammalian cells are mediated by cell cycle progression. Furthermore, inhibition of the cell cycle has become an effective strategy for eliminating cancer cells (20). The results of the present study demonstrated that the percentage proportion was reduced in the $\mathrm{S}$ phase cells and increased in the $\mathrm{G} 2 / \mathrm{M}$ phase cells following treatment with DPT in a dose-dependent manner, indicating that the inhibitory effect of DPT on QBC939 and RBE cellular proliferation is mediated by $\mathrm{G} 2 / \mathrm{M}$ phase cell cycle arrest. Previously, DPT was reported to induce inhibition of growth via cell cycle arrest in the G2/M phase of different cancer cell lines including HeLa leukemia (8-9) and non-small cell lung (10), gastric (11) and breast cancer (12) and glioblastoma (13) cells which is consistent with the results obtained in the present study.

It is known that cyclin protein and cyclin-dependent kinase (CDK) are two major components in cell cycle regulation (9), which can combine into the activated cyclin-CDK kinase complex to promote cell cycle transport. Among CDKs that regulate cell cycle progression, Cyclin $\mathrm{B}$, in association with CDK1, governs cell cycle progression by enhancing cell cycle distribution in the G2/M fraction (21). Entry into mitosis requires that $\mathrm{CDK} 1 / \mathrm{Cyclin} \mathrm{B}$ complexes are activated by Cdc25C phosphatase, which removes the inhibitory phosphorylation of CDK1 (22). To examine the mechanisms by which DPT led to G2/M phase arrest in QBC939 and RBE cells, the present study additionally investigated the status of key factors known to regulate cell cycle progression. The present result srevealed that DPT treatment significantly decreased the expression of Cyclin B1 and CDK1 suggesting that G2/M cell cycle arrest in cholangiocarcinoma cells is caused, at least in part, by changes in the Cyclin B1 and CDK1 protein levels.

Apoptosis is the process of programmed cell death, and is coupled with a number of clear morphological changes and cellular signaling pathways (23). The activation of apoptosis has been regarded as a target in cancer therapies (24). The morphological characteristics of apoptosis include condensation of cytoplasm and chromatin, chromosomal DNA fragmentation, and formation of apoptotic bodies (25). Therefore, the present study used Hoechst 33258 staining and flow cytometric assays to measure DPT induced apoptosis. In DPT-treated QBC939 and RBE cells, typical apoptotic changes of nuclear pyknosis and karyorrhexis are observed by Hoechst 33258 staining. Meanwhile, Annexin V staining results demonstrated that DPT significantly induced the apoptosis of QBC939 and $\mathrm{RBE}$ cells in a dose dependent manner $(\mathrm{P}<0.05)$. The results therefore suggest that DPT inhibited the proliferation of the QBC939 and RBE cells partially by inducing apoptosis.

In mammalian cells, death receptor induced extrinsic and mitochondria apoptosome mediated apoptotic intrinsic pathways are the two major pathways involved in the initiation of apoptosis (26). Bcl-2 family members and caspases perform a central role in controlling the two pathways. Mitochondria also 
A

$\mathrm{DPT}(\mu \mathrm{M})$

Cyclin B1

CDK1

Bax

$\mathrm{Bcl}-2$

Cleaved caspase 3

Cleaved caspase 8

Cleaved caspase 9

$\beta$-actin
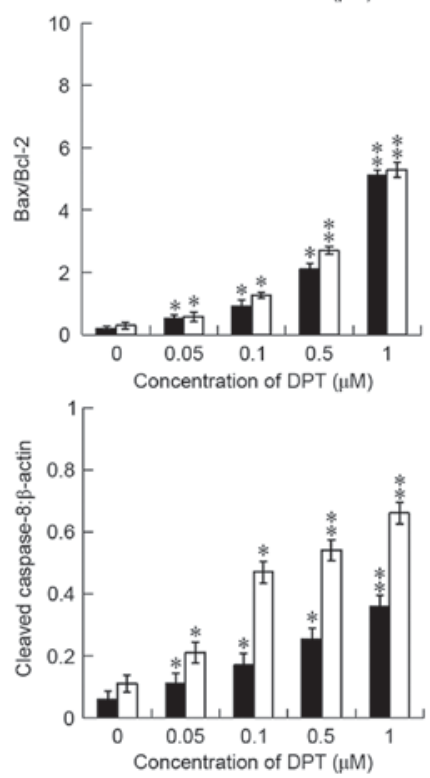

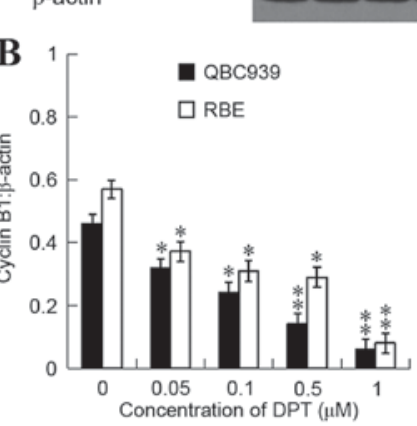

QBC939
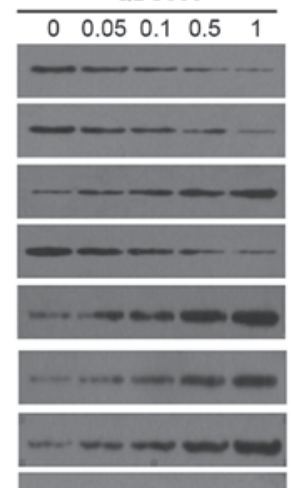
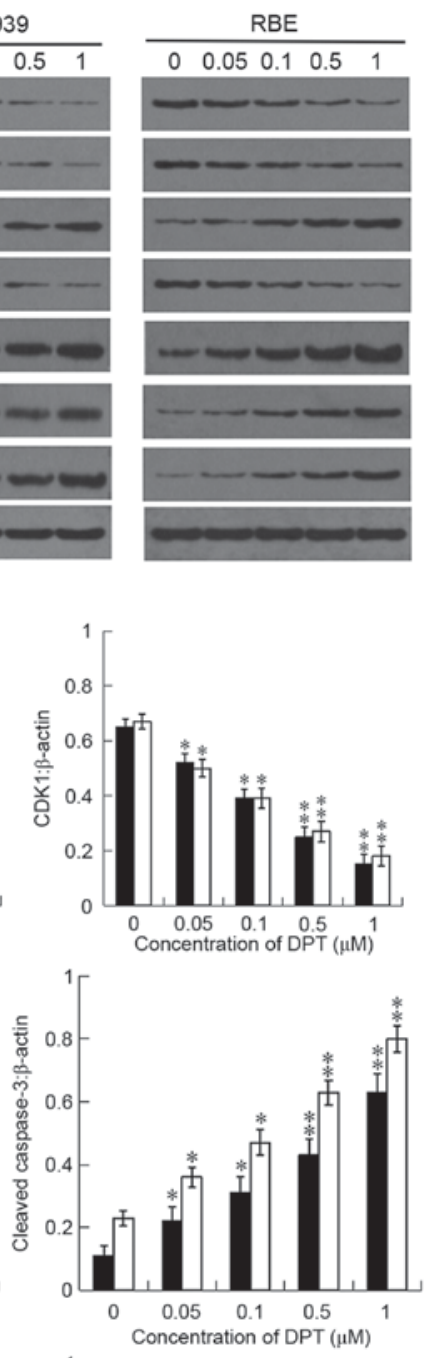

Figure 3. Effect of DPT on protein expression levels of Cyclin B1, CDK1, Bax, Bcl-2, cleaved caspase-3, cleaved caspase- 8 and cleaved caspase-9. QBC939 and RBE cells were incubated either with or without DPT $(0-1 \mu \mathrm{M})$ for $48 \mathrm{~h}$ and the expression levels of Cyclin B1, CDK1, Bax, Bcl-2, cleaved caspase-3, cleaved caspase- 8 and cleaved caspase- 9 were assessed by western blot analysis. (A) Western blot analysis of Cyclin B1, CDK1, Bax Bcl-2, cleaved caspase-3, cleaved caspase-8 and cleaved caspase- 9 expression levels, while $\beta$-actin was probed as the protein loading control. (B) Band densitometry analysis of Cyclin B1, CDK1, cleaved caspase-3, -8 and -9 expression levels normalized to $\beta$-actin and the rations of $\mathrm{Bax} / \mathrm{Bcl}-2$ in $\mathrm{QBC} 939$ and $\mathrm{RBE}$ cells. ${ }^{*} \mathrm{P}<0.05$ and ${ }^{* *} \mathrm{P}<0.01$ vs. control. DPT, deoxypodophyllotoxin. CDK1, cyclin dependent kinase-1; Bax, Bcl-2 associated X protein; Bcl-2, b-cell lymphoma-2.

perform a critical role in apoptosis induced by chemotherapeutic agents (27). Apoptosis is often associated with impaired mitochondrial adenine nucleotide exchange, the alternative channels in the mitochondrial outer membrane that permit the transit of adenine nucleotides (28). This process can be regulated by the
Bcl-2 family of proteins that govern the release of cytochrome $c$ from the mitochondria (29). The increased ratio of $\mathrm{Bax} / \mathrm{Bcl}-2$ induces the loss of mitochondrial membrane potential leading to permeability transition and cytochrome $c$ release. Furthermore, cytochrome $c$ activates caspase-9, which cleaves and activates the downstream effect of proteases, including caspase-3, thus triggering apoptosis (30). The cell death receptor pathway, mediated distinctively through active/cleaved caspase-8, performs an important role in the maintenance of tissue homeostasis. In addition, this pathway is characterized by binding cell death ligands and cell death receptors, and subsequently activates caspase-8, -3, -6 and -7 (31) and cleaved poly ADP-ribose polymerase. A number of studies have shown that DPT induces caspase-mediated apoptosis in a range of cancer cells (8-13) and affects numerous factors in cellular signal transduction pathways which are linked to the proapoptotic (Bax) and antiapoptotic (Bcl-2) gene $(9,10)$. Accordingly, in the present study, the elevated ratio of $\mathrm{Bax} / \mathrm{Bcl}-2$ and cleavage of caspase-3, -8 and -9 significantly increased the dose-dependent exposure to DPT. Generally, these findings indicated that intrinsic and extrinsic pathways are involved in DPT induced apoptosis.

In summary, the present results demonstrated, for the first time, that DPT is a potent growth inhibitor of cholangiocarcinoma cells. The growth inhibition is related to the $\mathrm{G} 2 / \mathrm{M}$ phase cell cycle arrest associated with the downregulation of Cyclin B1 and CDK1 and the induction of apoptosis via the intrinsic and extrinsic pathways. Thus, these results provide the basis for DPT as a promising agent against cholangiocarcinoma. However, the in vivo experiment and exact molecular mechanisms behind this needs additional investigations.

\section{Acknowledgements}

Not applicable.

\section{Funding}

The present study was supported by the Health Department Scientific Research Foundation of Hunan Province (grant no. 132012008).

\section{Availability of data and materials}

All data generated or analyzed during this study are included in this published article.

\section{Author's contributions}

MX, SP and XF conceived and designed the study. MX, YF, YZ and SL performed the experiments, analyzed the data and wrote the paper. MX, SP and XF reviewed and edited the manuscript. All authors read and approved the final manuscript.

\section{Ethics approval and consent to participate}

Not applicable.

\section{Consent for publication}

Not applicable. 


\section{Competing interests}

The authors declare that they have no competing interests.

\section{References}

1. Burger I, Hong K, Schulick R, Georgiades C, Thuluvath P, Choti M, Kamel I and Geschwind JF: Transcatheter arterial chemoembolization in unresectable cholangiocarcinoma: Initial experience in a single institution. J Vasc Interv Radiol 16 353-361, 2005

2. Gatto M, Bragazzi MC, Semeraro R, Napoli C, Gentile R, Torrice A, Gaudio E and Alvaro D: Cholangiocarcinoma: Update and future perspectives. Dig Liver Dis 42: 253-260, 2010.

3. Hammill CW and Wong LL: Intrahepatic cholangiocarcinoma: A malignancy of increasing importance. J Am Coll Surg 207: 594-603, 2008.

4. Yap TA and Workman P: Exploiting the cancer genome: Strategies for the discovery and clinical development of targeted molecular therapeutics. Annu Rev Pharmacol Toxicol 52: 549-573, 2012.

5. Ikeda R, Nagao T, Okabe H, Nakano Y, Matsunaga H, Katano M and Mori M: Antiproliferative constituents in umbelliferae plants. III. Constituents in the root and the ground part of Anthriscus sylvestris Hoffm. Chem Pharm Bull 46: 871-874, 1998.

6. Masuda T, Oyama Y, Yonemori S, Takeda Y, Yamazaki Y, Mizuguchi S, Nakata M, Tanaka T, Chikahisa L, Inabak Y and Okada Y: Flow cytometric estimation on cytotoxic activity of leaf extracts from seashore plants in subtropical Japan: Isolation, quantification and cytotoxic action of (-)-deoxypodophyllotoxin. Phytother Res 16: 353-358, 2002.

7. Muto N, Tomokuni T, Haramoto M, Tatemoto H, Nakanishi T, Inatomi Y, Murata $\mathrm{H}$ and Inada $\mathrm{A}$ : Isolation of apoptosis- and differentiation-inducing substances toward human promyelocytic leukemia HL-60 cells from leaves of Juniperus taxifolia. Biosci Biotechnol Biochem 72: 477-484, 2008.

8. Yong Y, Shin SY, Lee YH and Lim Y: Antitumor activity of deoxypodophyllotoxin isolated from Anthriscus sylvestris: Induction of $\mathrm{G} 2 / \mathrm{M}$ cell cycle arrest and caspase-dependent apoptosis. Bioorg Med Chem Lett 9: 4367-4371, 2009.

9. Shin SY, Yong Y, Kim CG, Lee YH and Lim Y: Deoxypodophyllotoxin induces G2/M cell cycle arrest and apoptosis in HeLa cells. Cancer Lett 287: 231-239, 2010.

10. Wu M, Jiang Z, Duan H, Sun L, Zhang S, Chen M, Wang Y, Gao Q, Song Y, Zhu X and Zhang L: Deoxypodophyllotoxin triggers necroptosis in human non-small cell lung cancer NCI-H460 cells. Biomed Pharmacother 67: 701-706, 2013.

11. Wang YR, Xu Y, Jiang ZZ, Guerram M, Wang B, Zhu X and Zhang LY: Deoxypodophyllotoxin induces G2/M cell cycle arrest and apoptosis in SGC-7901 cells and inhibits tumor growth in vivo. Molecules 20: 1661-1675, 2015.

12. Benzina S, Harquail J, Jean S, Beauregard AP, Colguhoun CD, Carroll M, Bos A, Gray CA and Robichaud GA: Deoxypodophyllotoxin isolated from Juniperus communis induces apoptosis in breast cancer cells. Anticancer Agents Med Chem 15: 79-88, 2015.
13. Mounia G, Jiang ZZ, Sun LX, Zhu X and Zhang LX Antineoplastic effects of deoxypodophyllotoxin, a potent cytotoxic agent of plant origin, on glioblastoma U-87 MG and SF126 cells. Pharmacol Rep 67: 245-252, 2015

14. Lee SH, Son MJ, Ju HK, Lin CX, Moom TC, Choi HG, Son JK and Chang HW: Dual inhibition of cyclooxygenases-2 and 5-lipoxygenase by deoxypodophyllotoxin in mouse bone narrow-derivd mast cells. Biol Pharm Bill 27: 786-788, 2004.

15. Sudo K, Konno K, Shigeta S and Yokota T: Inhibitory effects of podophyllotoxin derivatives on herpes simplex virus replication. Antivir Chem Chemother 9: 263-267, 1998.

16. Evan GI and Vousden KH: Proliferation, cell cycle and apoptosis in cancer. Nature 411: 342-348, 2001.

17. Niemann-Jönsson A, Ares MP, Yan ZQ, Bu DX, Fredrikson GN, Brånén L, Pörn-Ares I, Nilsson AH and Nilsson J: Increased rate of apoptosis in intimal arterial smooth muscle cells through endogenous activation of TNF receptors. Arterioscler Thromb Vasc Biol 21: 1909-1914, 2001.

18. Meier P, Finch A and Evan G: Apoptosis in development. Nature 407: 796-801, 2000

19. Lizotte E, Tremblay A, Allen BG and Fiset C: Isolation and characterization of subcellular protein fractions from mouse heart. Anal Biochem 345: 47-54, 2015.

20. Cho JH, Lee JG, Yang YI, Kim JH, Ahn JH, Baek NI, Lee KT and Choi JH: Eupatilin, a dietary flavonoid, induces G2/M cell cycle arrest in human endometrial cancer cells. Food Chem Toxicol 49: 1737-1744, 2011.

21. Taylor WR and Stark GR: Regulation of the G2/M transition by p53. Oncogene 20: 1803-1815, 2001.

22. Smits VJ and Medema RH: Checking out the $\mathrm{G}(2) / \mathrm{M}$ transition. Biochim Biophys Acta 1519: 1-12, 2001.

23. Yang R, Liu A, Ma X, Li L, Su D and Liu J: Sodium tanshinone IIA sulfonate protects cardiomyocytes against oxidative stress-mediated apoptosis through inhibiting JNK activation. J Cardiovasc Pharmacol 51: 396-401, 2008.

24. Hengartner MO: The biochemistry of apoptosis. Nature 407: 770-776, 2000

25. Neto CC, Amoroso JW and Liberty AM: Anticancer activities of cranberry phytochemicals: An update. Mol Nutr Food Res 52 (Suppl 1): S18-S27, 2008.

26. Wei H and John JK: Anticancer therapy targeting the apoptotic pathway. Oncology 4: 721-729, 2003.

27. Delivani $P$ and Martin SJ: Mitochondrial membrane remodeling apoptosis: An inside story. Cell Death Differ 13: 2007-2010, 2006.

28. Vander Heiden MG, Chandel NS, Williamson EK, SchumackerPT and Thompson CB: Bcl-xL regulates the membrane potential and volume homeostasis of mitochondria. Cell 91: 627-637, 1997.

29. Cory S and Adams JM: The Bcl2 family: Regulators of the cellular life-or-death switch. Nat Rev Cancer 2: 647-656, 2002.

30. Green DR: Apoptotic pathways: Ten min to dead. Cell 121: 671-674, 2005.

31. Liu X, Yue P, Zhou Z, Khuri FR and Sun SY: Death receptor regulation and celecoxib-induced apoptosis in human lung cancer cells. J Natl Cancer Inst 96: 1769-1780, 2004. 